\title{
KERAGAAN SPERMATOZOA UDANG WINDU (Penaeus monodon FAB.) ASAL LAUT DAN TAMBAK
}

\author{
Samuel Lante") dan Haryanti")
}

\begin{abstract}
ABSTRAK
Pengamatan keragaan spermatozoa induk udang windu ( $P$. monodon Fab.) jantan asal laut dan tambak telah dilakukan. Riset ini bertujuan untuk mengetahui keragaan spermatopora, meliputi bobot spermatopora, jumlah, persentase hidup, dan abnormalitas spermatozoa. Sampel induk udang windu diperoleh dari tiga lokasi yaitu dari alam (perairan Sumbawa, Nusa Tenggara Barat, dan Banyuwangi, Jawa timur) dan dari tambak Pejarakan, Bali. Hasil riset menunjukkan bahwa bobot spermatopora udang alam dari perairan Sumbawa dan Banyuwangi tidak ada perbedaan keragaan spermatopora $(P>0,05)$. Namun, bila dibandingkan dengan keragaan spermatopora udang asal tambak, induk dari kedua perairan tersebut mempunyai keragaan spermatopora yang berbeda nyata $(P<0,05)$. Hasil ini menunjukkan bahwa keragaan spermatozoa induk alam asal perairan Sumbawa dan Banyuwangi lebih tinggi dibandingkan dengan keragaan spermatozoa induk udang asal tambak. Induk alam dari perairan Sumbawa memiliki jumlah spermatozoa $192,998 \pm 76,681 \times 10^{3}$ sel persentase hidup spermatozoa sebesar $79,80 \%$ $\pm 11,45 \%$ dan persentase abnormalitas spermatozoa sebesar $25,96 \% \pm 8,11 \%$. Sementara, induk yang berasal dari perairan Banyuwangi mempunyai jumlah spermatozoa 93,127 $\pm 58,344$ $\times 10^{3}$ sel, persentase hidup $54,17 \% \pm 28,14 \%$, dan abnormalitas spermatozoa $41,51 \% \pm 18,50 \%$. Keragaan spermatopora untuk udang asal tambak menunjukkan jumlah spermatozoa 58,750 \pm $25,193 \times 10^{3}$ sel, persentase hidup spermatozoa $66,86 \% \pm 24,0 \%$, dan persentase abnormalitas spermatozoa $34,78 \% \pm 14,82 \%$.
\end{abstract}

\begin{abstract}
Spermatozoa peiformances of black tiger shrimp broodstock (Penaeus monodon Fab.) from wild and pond cultured, by: Samuel Lante and Haryanti

The aim of this study was to know the spermatozoa performances of black tiger shrimp broodstock. (P. monodon) from the wild and pond cultured. Some variables were observed i.e. spermatophore weight, number of spermatozoa, percentages of life, and abnormality of spermatozoa. Male broodstock samples were collected from three locations i.e. from Sumbawa, West Nusa Tenggara waters and Banyuwangi (East Java) waters, and from pond cultured in PejarakanBali. Results of the study indicated that spermatophore weight of wild shrimp from Sumbawa and Banyuwangi waters were not significantly different $(P>0.05)$, but compared to the shrimp from pond cultured the both were significantly different $(P<0.05)$. The result indicated that performance of wild shrimp spermatozoa from Sumbawa and Banyuwangi waters were higher compared to the shrimp spermatozoa from pond cultured. The wild shrimp from Sumbawa waters have spermatozoa number of $192.998 \pm 76.681 \times 10^{3}$ cell, life spermatozoa percentages of $79.80 \% \pm 11.45 \%$, and abnormal spermatozoa percentages of $25.96 \% \pm 8.11 \%$, while spermatozoa performance of shrimp from Banyuwangi waters have spermatozoa number of $93,127 \pm 58.344 \times 10^{3}$ cell, life spermatozoa percentages of $54.17 \% \pm 28.14 \%$, and abnormal spermatozoa percentages of $41.51 \% \pm 18.50 \%$. The pond cultured shrimp have spermatozoa number of $58.750 \pm 25.193 \times 10^{3}$ cell, life spermatozoa percentages of $66.86 \% \pm 24.0 \%$, and abnormal spermatozoa percentages of $34.78 \% \pm 14.82 \%$
\end{abstract}

KEYWORDS: black tiger shrimp, spermatozoa, wild and pond cultured broodstock

\section{PENDAHULUAN}

Eksploitasi yang berlebihan terhadap induk udang windu asal laut berdampak pada menurunnya populasi di alam. Hal ini akan berdampak pula pada kualitas induk jantan yang digunakan untuk perbenihan terutama pada daya tetas telur dan larva yang dihasilkan. Penurunan daya tetas telur diduga disebabkan oleh kualitas spermatozoa induk udang jantan. Mutu spermatozoa kurang memadai terutama adanya kerusakan pada ekor sperma udang Penaeus setiferus, pertama kali dilaporkan oleh Brown et al. (1979). Analisis mutu spermatopora dilakukan pertama kali oleh Leung-Trujillo \& Lawrence (1985)

Peneliti pada Balai Riset Perikanan Budidaya Air Payau, Maros

Peneliti pada Balai Besar Riset Perikanan Budidaya Laut, Gondol 
terhadap bobot spermatopora, jumlah spermatozoa, dan persentase abnormalitas spermatozoa induk Penaeus vannamei asal perairan Mexico, Penaeus setiferus asal perairan Arkansas, Texas (Leung-Trujillo \& Lawrence (1987), dan bobot spermatopora, jumlah spermatozoa, persentase abnormalitas, dan persentase hidup spermatozoa udang windu asal perairan Philipina (Gomes \& Primavera, 1993), serta mutu spermatozoa udang windu asal perairan Thailand dilaporkan oleh Pratoomchat et al. (1993), sedangkan mutu spermatozoa udang windu asal tambak telah diamati oleh Lante et al., (1997). Selanjutnya mutu spermatozoa udang putih ( $P$. vanname $)$ asal tambak oleh Alfaro \& Lozano (1993), Heitzman et al. (1993), dan mutu spermatozoa udang biru ( $P$. stylirostris) asal tambak oleh Alfaro (1993). Hasil penelitian di atas menyimpulkan bahwa mutu spermatozoa udang berhubungan erat dengan geografis lingkungan, kualitas air, dan jenis makanan dari perairan dimana udang hidup.

Sumber utama induk udang windu di Indonesia untuk pembenihan pada umumnya berasal dari perairan Sumatera (Aceh), Jawa, Kalimantan, Sulawesi, dan Sumbawa, Nusa Tenggara Barat (NTB). Moria et al. (2002) melaporkan bahwa dibandingkan dengan induk udang yang berasal dari perairan Jawa dan perairan Sulawesi maka induk udang betina yang berasal dari Aceh dan Sumbawa mempunyai variasi gen yang lebih tinggi, diindikasikan oleh tingkat heterosigositas dan jumlah alel perlokus. Namun informasi kualitas spermatozoa induk udang windu dari laut dan tambak masih terbatas. Berdasarkan informasi di atas maka dilakukan pengamatan terhadap kualitas spermatozoa udang windu jantan asal perairan laut dan tambak seperti dari perairan Sumbawa (NTB), perairan Banyuwangi (Jawa Timur), dan induk asal tambak (Bali). Riset ini bertujuan untuk mendapatkan informasi tentang mutu spermatozoa yang meliputi bobot spermatopora, jumlah spermatozoa, persentase hidup, dan abnormalitas spermatozoa. Hasil yamg diperoleh diharapkan dapat memberikan gambaran kualitas spermatozoa udang asal laut dan tambak untuk keperluan perbenihan jangka panjang yang berkelanjutan.

\section{BAHAN DAN METODE}

Hewan uji induk udang windu ( $P$. monodon Fab.) jantan diperoleh dari tiga lokasi yaitu: dua dari alam (perairan Sumbawa, NTB dengan bobot tubuh 80,40 $\pm 9,95 \mathrm{~g}$ dan perairan Banyuwangi dengan bobot 79,77 $\pm 9,30 \mathrm{~g}$ ) dan satu asal tambak Pejarakan, Bali dengan bobot 69,75 $\pm 7,91 \mathrm{~g}$. Induk yang digunakan untuk analisis masing-masing lokasi sebanyak 15 ekor, kemudian dipindahkan ke laboratorium untuk diadaptasi selama 1 (satu) minggu dalam bak pemeliharaan. Selama proses adaptasi udang diberi pakan segar (cumi-cumi dan udang kecil) sebanyak $15 \%$ dari total biomassa udang. Spermatopora dari masing-masing udang dikeluarkan mengikuti metode Leung-Trujillo \& Lawrence (1985) dengan menggunakan transformer elektrik yang dilengkapi dua elektroda. Kedua elektroda ditempelkan dekat kaki renang ke-5 dengan rangsangan aliran listrik 4-20 volt $A C$. Dengan adanya kejutan secara teratur, induk jantan mengeluarkan spermatopora secara perlahanlahan. Selanjutnya spermatopora dimasukkan dalam tabung dan ditambahkan 3,0 mL larutan $\mathrm{Ca}^{2+}$ bebas garam serta dihomogenkan dengan homogeniser dan diwarnai dengan triphan blue. Setelah homogen, spermatozoa diambil 0,1 $\mathrm{mL}$ diteteskan pada hemacitometer untuk diamati di bawah mikroskop dan dihitung jumlah spermatozoa. Parameter yang diamati meliputi: bobot spermatopora menggunakan timbangan kepekaan 0,001 g, jumlah spermatozoa, persentase hidup spermatozoa dihitung dengan menggunakan metode Alfaro (1993) yaitu jumlah hidup spermatozoa dibagi total sel spermatozoa pengamatan dikalikan seratus persen, sedangkan persentase abnormalitas spermatozoa dengan menggunakan metode Leung-Trujillo \& Lawrence (1987). Spermatozoa abnormal ditandai dengan bintik di kepala, ekor putus, dan bengkok, sedangkan spermatozoa hidup memperlihatkan warna terang kebiru-biruan apabila diberi zat pewarna dan spermatozoa mati memperlihatkan warna biru kehitam-hitaman disebabkan selaput luar spermatozoa telah mati. Data persentase abnormalitas spermatozoa ditransformasikan ke arcsin. Untuk mengetahui pengaruh perlakuan data bobot spermatopora, jumlah spermatozoa, persentase hidup, dan abnormalitas spermatozoa dianalisis secara statistik sistem software prosedur general linear model dilanjutkan dengan uji beda nyata terkecil (BNT) pada tingkat kepercayaan $95 \%$.

\section{HASIL DAN BAHASAN}

Hasil uji statistik menunjukkan bahwa bobot spermatopora udang windu jantan (Gambar 1) asal perairan Sumbawa dan Banyuwangi tidak berbeda nyata $(P>0,05)$. Tetapi bobot spermatopora udang dari kedua perairan tersebut lebih tinggi $(P<0,05)$ bila dibandingkan dengan bobot spermatopora induk udang asal tambak (Tabel 1). Hasil pengamatan ini sesuai dengan hasil penelitian yang dilaporkan Pratoomchat (1993) yang menyatakan bahwa bobot spermatopora udang windu asal laut berbeda nyata $(P<0,05)$ bila dibandingkan dengan bobot spermatopora udang asal tambak. Satu di antara indikator yang diekspresikan dari bobot spermatopora yang rendah adalah korelasinya terhadap kualitas spermatozoa yang 
rendah pula, terutama adanya abnormalitas spermatozoa yang tinggi seperti dilaporkan oleh Motoh (1981) serta Leung-Trujillo \& Lawrence (1985) masing-masing pada udang windu dan $P$. vannamei. Adanya perbedaan berat spermatopora pada pengamatan ini diduga karena ukuran induk udang yang bervariasi. Ukuran induk udang asal perairan Sumbawa dan perairan Banyuwangi lebih besar dibanding ukuran udang asal tambak. Nampaknya, dengan berat yang lebih besar, udang berpotensi menghasilkan spermatozoa yang lebih banyak (Alfaro, 1993; Lante et al., 1997). Berat spermatopora udang windu asal perairan Sumbawa dan perairan Banyuwangi yang diperoleh pada pengamatan ini lebih rendah bila dibandingkan dengan berat spermatopora udang windu asal perairan Philipina $(0,177 \mathrm{~g})$ dengan rata-rata bobot tubuh 68,6 g/ekor (Gomes \& Primavera, 1993). Namun, keadaan ini masih lebih tinggi bila dibandingkan dengan bobot spermatopora udang windu $(0,057 \mathrm{~g})$ dengan bobot udang berkisar 46-138 g/ekor yang berasal dari perairan timur Teluk Thailand seperti dilaporkan oleh Pratoomchat et al. (1993). Sebaliknya, hasil pengamatan bobot spermatopora udang asal tambak lebih tinggi bila dibandingkan dengan berat spermatopora udang windu asal tambak di Thailand $(0,043 \mathrm{~g})$ dengan bobot udang berkisar antara 50-90 g/ekor (Pratoomchat et al., 1993), tetapi mendekati bobot spermatopora udang windu asal tambak $(0,08$ g) yang dilaporkan oleh Lante (1998).

Spermatopora memegang peranan penting dalam pemindahan dan penyimpanan spermatozoa pada udang. Selain itu, spermatopora memberikan perlindungan terhadap spermatozoa dan berfungsi dalam melengkapi kebutuhan energi spermatozoa selama tersimpan pada udang betina (Subramoniam, 1990). Pembentukan spermatopora berhubungan erat dengan siklus ganti kulit pada udang. Selanjutnya Heitzman et al., (1993) menyatakan bahwa pembentukan spermatopora baru terlepas dari ada tidaknya spermatopora dalam terminal ampulla. Alfaro (1993) menguraikan bahwa bobot spermatopora tidak dapat dijadikan indikator untuk jumlah spermatozoa dalam spermatopora, karena spermatopora bukan saja disusun oleh spermatozoa tetapi juga disusun oleh jaringan lapisan luar spermatopora yang tersusun dalam saluran spermatozoa. Lapisan luar spermatopora tersebut merupakan mukopolisakarida yang tersusun dari bahan basophilic dan eosinophilic seperti dilaporkan oleh Subramoniam (1990). Selanjutnya, lapisan luar spermatopora berperan mencegah spermatozoa dari kerusakan yang disebabkan oleh infeksi mikroba selama penyimpanan pada telikum udang betina sebelum spermatozoa digunakan untuk pembuahan.

Jumlah spermatozoa udang windu asal perairan Sumbawa lebih banyak bila dibandingkan dengan jumlah spermatozoa udang yang berasal dari perairan Banyuwangi dan tambak. Selanjutnya jumlah spermatozoa udang asal perairan Banyuwangi lebih banyak dari pada jumlah spermatozoa udang asal Tambak (Tabel 1). Hasil pengamatan ini memperlihatkan bahwa jumlah spermatozoa udang asal

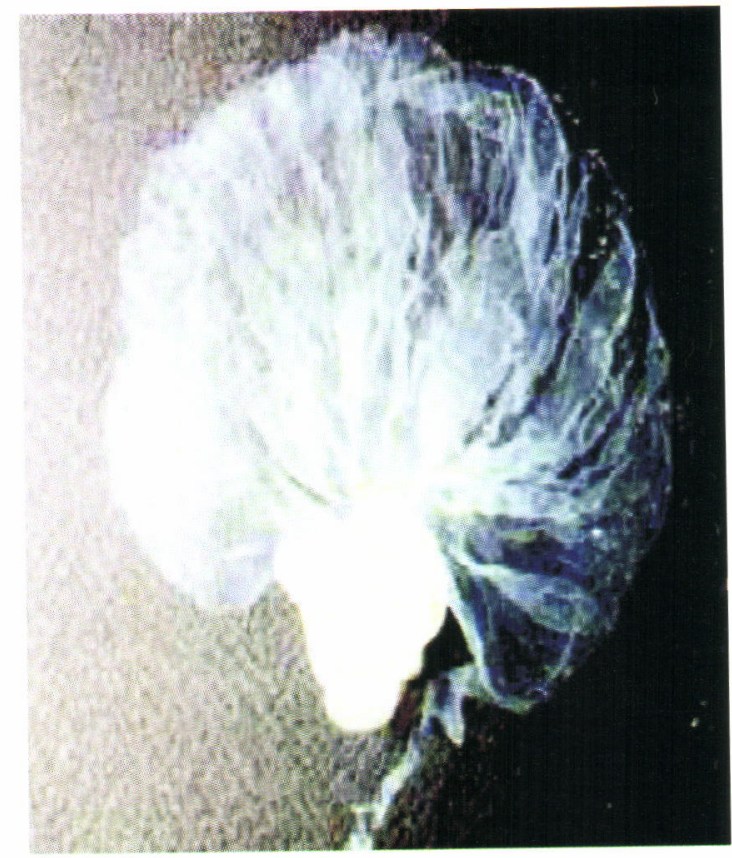

Gambar 1. Spermatopora udang windu (P. monodon) Figure 1. Spermatophore of black tiger shrimp (P. monodon) 
Tabel 1. Rataan bobot udang, spermatopora, jumlah spermatozoa, persentase hidup, dan abnormalitas spermatozoa udang windu ( $P$. monodon Fab.) asal laut dan tambak

Table 1. Average of body weight, spermatophore weight, total of spermatozoa, percentages of life, and abnormality of spermatozoa from wild and pond cultured broodstock

\begin{tabular}{|c|c|c|c|}
\hline \multirow{2}{*}{ Variabel } & \multicolumn{3}{|c|}{$\begin{array}{l}\text { Induk udang windu asal laut dan tambak } \\
\text { Black tiger shrimp from wild and pond cultured broodstock }\end{array}$} \\
\hline & $\begin{array}{l}\text { Perairan Sumbawa } \\
\text { Sumbawa waters }\end{array}$ & $\begin{array}{l}\text { Tambak Banyuwangi } \\
\text { Banyuwangi waters }\end{array}$ & $\begin{array}{l}\text { Tambak Pejarakan } \\
\text { Pond cultured }\end{array}$ \\
\hline $\begin{array}{l}\text { Bobot udang } \\
\text { Shrimp body weight }(\mathrm{g})\end{array}$ & $80.40 \pm 9.95$ & $79.77 \pm 9.30$ & $69.75 \pm 7.91$ \\
\hline $\begin{array}{l}\text { Bobot spermatopora } \\
\text { Spermatophore weight }(\mathrm{g})\end{array}$ & $0.126^{a} \pm 0.025$ & $0.126^{a} \pm 0.026$ & $0.086^{b} \pm 0.023$ \\
\hline $\begin{array}{l}\text { Jumlah sperma tozoa spermatopora } \\
\text { Total of spermatozoa spermatophore }\end{array}$ & $192,998^{a} \pm 76,681$ & $93,127^{b} \pm 8,344$ & $58,750^{c} \pm 25,193$ \\
\hline $\begin{array}{l}\text { Persentase hidup sperma } \\
\text { Life sperm percentages }\end{array}$ & $79.80^{a} \pm 11.45$ & $54.17^{b} \pm 28.14$ & $66.86^{b} \pm 24.00$ \\
\hline $\begin{array}{l}\text { Persentase abnormalitas sperma } \\
\text { Sperm abnormalality percentages (\%) }\end{array}$ & $25.96 a \pm 8.11$ & $41.51^{b} \pm 18.50$ & $34.78^{b} \pm 14.82$ \\
\hline
\end{tabular}

Angka yang diikuti dengan huruf yang sama pada baris yang sama tidak berbeda nyata $(P>0,05)$

Values followed by the same letter on the same lines are not significantly different $(P>0.05)$

perairan Sumbawa dua kali lebih besar dari jumlah spermatozoa udang asal perairan Banyuwangi serta tiga kali lebih besar dibandingkan jumlah spermatozoa udang asal tambak. Jumlah spermatozoa udang asal perairan Sumbawa dan udang asal perairan Banyuwangi yang diperoleh dalam penelitian ini lebih tinggi dibandingkan dengan jumlah spermatozoa $\left(77,53 \times 10^{6} \mathrm{sel}\right)$ udang windu (bobot tubuh $68,6 \mathrm{~g} /$ ekor) yang berasal dari perairan Philipina (Gomes \& Primavera, 1993) dan jumlah spermatozoa $(47,247 x$ $10^{3} \mathrm{sel}$ ) udang windu (bobot tubuh berkisar $46-138$ g/ekor) asal perairan Thailand, Pratoomchat et al. (1993)

Perbedaan jumlah spermatozoa yang dihasilkan antara udang asal perairan Sumbawa dan perairan Banyuwangi diduga disebabkan oleh perbedaan kondisi lingkungan perairan serta tingkat eksploitasi penangkapan induk di perairan Sumbawa yang masih rendah (Tridjoko et al., 1992). Di perairan Sumbawa, dengan kondisi perairan yang langsung berhadapan dengan Samudera Hindia dengan kondisi arus yang besar aktivitas manusia masih relatif rendah. Sementara, untuk perairan Banyuwangi mempunyai arus yang relatif pelan karena berhadapan dengan Laut Jawa, aktivitas manusia tinggi terlihat dengan banyaknya hatcheri dan kapal penyeberangan.

Hal lain yang menyebabkan jumlah spermatozoa udang windu asal perairan Banyuwangi lebih rendah dibandingkan dengan spermatozoa udang windu asal perairan Sumbawa diduga disebabkan oleh kualitas pakan alami yang menurun akibat peningkatan bahan organik dan kandungan sulfida serta mobilisasi kegiatan industri seperti: industri perusahaan pakan, cold storages, pendaratan ikan yang banyak beroperasi di sekitar perairan Banyuwangi (Jatim) serta penurunan $\mathrm{pH}$ dan kelimpahan plankton yang menurun karena limbah dari aktivitas kegiatan pertanian dan pemukiman sehingga berdampak pada perubahan kondisi dasar sedimen yang dapat memicu degradasi kualitas lingkungan perairan.

Selanjutnya Lante \& Tsumura (2004) melaporkan bahwa kualitas air tambak asal induk udang yang diamati masih relatif baik dan layak untuk budi daya tambak dalam rangka produksi induk udang. Menurut Anonim (2002), melaporkan bahwa kualitas lingkungan perairan menurun oleh karena terjadi peningkatan bahan organik, penurunan $\mathrm{pH}$, pengurangan komposisi bentos, peningkatan kandungan sulfida, dan ammonia.

Jumlah spermatozoa udang windu asal tambak $\left(58,750 \times 10^{3} \mathrm{sel}\right)$ adalah terendah bila dibandingkan dengan induk udang yang berasal dari alam, tetapi masih lebih tinggi dibanding jumlah spermatozoa udang windu asal tambak di Thailand $\left(29,26 \times 10^{3}\right.$ sel) seperti dilaporkan oleh Pratoomchat et al. (1993), namun lebih rendah bila dibanding jumlah spermato- 
zoa udang asal tambak $\left(105,8 \times 10^{3}\right.$ sel) yang dilaporkan oleh Lante(1998). Perbedaan jumlah spermatozoa antara udang asal laut dan udang asal tambak diduga karena umur induk udang asal tambak yang dipakai dalam pengamatan ini kurang dari satu tahun (10 bulan pemeliharaan). Padahal Cases-Borja \& Rasalan dalam Nurdjana (1985) melaporkan bahwa udang windu asal tambak siap digunakan sebagai induk setelah dipelihara selama satu tahun. Selanjutnya jumlah spermatozoa rendah dikarenakan sumber makanan di tambak terbatas seperti yang dilaporkan oleh Lante \& Haryanti (1997). Tambak Pejarakan-Bali sebagai tempat budi daya untuk menghasilkan induk udang windu relatif rendah unsur haranya sebagai sumber bagi penumbuhan pakan alami (bentos dan udang-udang kecil), sehingga sangat bergantung pada masukan bahan organik ke dalam tambak seperti pemberian pakan buatan dan pemupukan. Selanjutnya udang windu asal tambak dipengaruhi oleh teknik pemeliharaan yang diterapkan dan jenis makanan yang diberikan. Makanan udang windu yang sedang berkembang sel telur dan spermanya adaiah berupa kepiting, cumi-cumi, kerang, dan udang kecil seperti yang dilaporkan oleh Tridjoko et al. (1993).

Ranoemihardjo et al. (1980) melaporkan hasil analisis isi perut udang asal tambak menunjukkan bahwa makanannya terdiri atas plankton jenis Lyngbya sp., Spirulina sp., dan Skeletonema sp. Sedangkan di alam kualitas dan kuantitas makanan yang dimakan lebih beranekaragamı. Marte dalam Nurdjana (1985) melaporkan bahwa makanan udang di laut terdiri atas $80 \%$ krustase (kepiting dan udang kecil), $5 \%$ moluska, dan $15 \%$ campuran ikan, cacing, kotoran, dan bijibijian, namun di tambak terdiri atas: copepoda, udangudang kecil, dan cacing. Dengan demikian semakin baik mutu, jenis dan beranekaragamnya makanan yang dimakan serta didukung lingkungan perairan yang baik maka jumlah spermatozoa yang dihasilkan semakin meningkat. Kualitas spermatozoa ditentukan oleh kenormalan dan persentase hidup spermatozoa serta perkembangan udang, lingkungan, dan makanan selama di alam maupun tambak.

Persentase hidup spermatozoa udang asal perairan Sumbawa adalah sebesar $79,80 \%$ lebih tinggi $(P<0,05)$ bila dibanding persentase hidup spermatozoa udang asal perairan Banyuwangi dan udang asal tambak, tetapi antara persentase hidup spermatozoa udang asal perairan Banyuwangi dan udang asal tambak adalah sama $(P>0,05)$ (Tabel 1). Bila dilihat dari normalitas spermatozoa udang ternyata menunjukkan hubungan yang sangat erat antara asal induk udang dengan lingkungan perairan. Keragaan spermatozoa udang asal perairan Sumbawa lebih baik dibanding keragaan spermatozoa udang asal perairan Banyuwangi dan asal tambak dihitung dari persentase jumlah spermatozoa yang hidup dan aktif. Persentase spermatozoa yang hidup pada udang asal perairan Sumbawa lebih tinggi daripada udang asal perairan Banyuwangi dan udang asal tambak.

Hal ini terlihat jelas bahwa dalam pengamatan secara mikroskopis (Gambar 2) menunjukkan bahwa

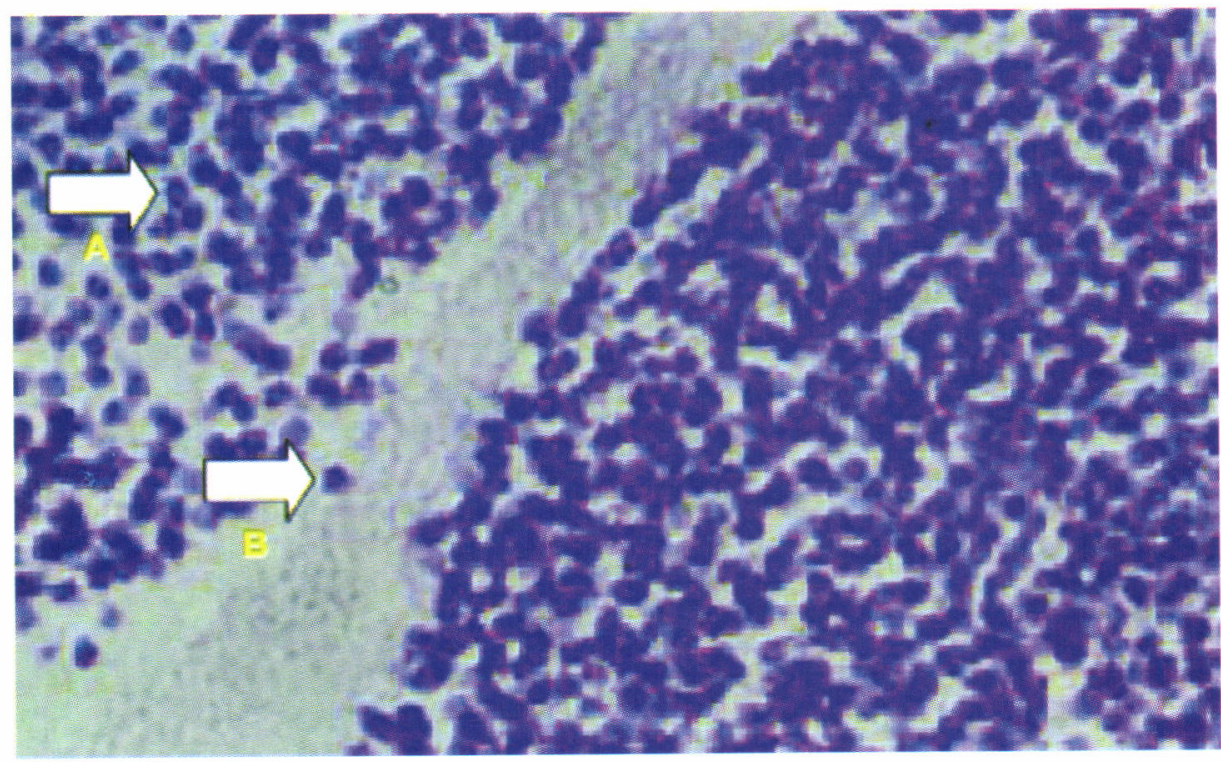

Gambar 2. Spermatozoa udang windu (P. monodon) (A) normal dan (B) abnormal spermatozoon selama pengamatan

Figure 2. Spermatozoa of black tiger shrimp (P. monodon) (A) normal and (B) abnormal spermatozoon during experiment 
spermatozoa yang hidup pada udang asal perairan Sumbawa lebih banyak memperlihatkan warna terang kebiru-biruan dan memiliki susunan morfologi spermatozoa yang lengkap yaitu kepala, leher, ekor, dan ujung ekor. Sedangkan penampakan spermatozoa abnormal lebih sedikit dengan memperlihatkan warna biru kehitam-hitaman. Spermatozoa hidup dicirikan dengan tidak adanya zat warna yang diberikan seperti dilaporkan oleh Nalbandov (1990). Persentase hidup spermatozoa tertinggi yang diperoleh dalam pengamatan ini lebih rendah dibanding dengan persentase hidup spermatozoa (100\%) udang windu asal perairan Philipina (Gomes \& Primavera, 1993), dan persentase hidup spermatoza $(99,0 \%)$ udang Penaeus setiferus asal perairan Arkansas, Texas (Leung-Trujillo \& Lawrence, 1987). Salah satu faktor yang mempengaruhi menurunnya keragaan spermatozoa diduga adanya infeksi jenis bakteri. Infeksi bakteri dalam jumlah banyak akan menurunkan jumlah spermatozoa (Leung-Trujillo \& Lawrence, 1987), namun pada penelitian ini tidak dilakukan pengamatan terhadap adanya infeksi jenis bakteri. Selanjutnya dikatakan bahwa umur udang berpengaruh terhadap kualitas spermatozoa (jumlah hidup spermatozoa dan abnormalitasnya).

Persentase abnormalitas spermatozoa udang asal perairan Sumbawa adalah $25,96 \%$ lebih tinggi $(P<0,05)$ bila dibanding persentase abnormal spermatozoa udang asal perairan Banyuwangi dan udang asal tambak, tetapi persentase abnormal spermatozoa antara udang asal perairan Banyuwangi dan asal tambak tidak menunjukkan perbedaan $(P>0,05)$. Hasil ini memperlihatkan bahwa tingkat abnormalitas spermatozoa tertinggi didapatkan pada induk udang asal tambak dan terendah pada udang asal perairan Sumbawa. Dengan persentase abnormalitas spermatozoa yang tinggi dapat diindikasikan bahwa keragaan spermatozoa induk udang rendah, tetapi sebaliknya persentase abnormalitas spermatozoa rendah menunjukkan keragaan spermatozoa induk udang baik. Abnormalitas spermatozoa udang sangat erat hubungannya dengan asal lingkungan perairan. Spermatozoa abnormal disebabkan jaringan selaput luar telah mati sehingga apabila diberi zat pewarna, zat warna meresap masuk kedalam sel spermatozoa (Lante, 1998). Selanjutnya Nalbandov (1990) melaporkan bahwa spermatozoa abnormal mengikat zat warna dan berpengaruh buruk terhadap kemampuan fertilisasi sel yang normal. Pengamatan mikroskop menunjukkan bahwa abnormalitas spermatozoa memperlihatkan bentuk kepala cacat (terlihat ada bintik, ekor putus, dan bengkok) sedangkan pada spermatozoa normal kepala tidak cacat dan ekor utuh (tidak putus). Hasil pengamatan ini sesuai dengan hasil penelitian (Leung-Trujillo \&
Lawrence, 1987; Alfaro, 1993; Alfaro \& Lozano, 1993). Tingginya abnormalitas spermatozoa pada induk udang asal tambak diduga dipengaruhi oleh rendahnya kualitas pakan yang dimakan udang selama dipelihara di tambak. Dengan demikian pengamatan kualitas spermatozoa induk udang jantan asal perairan Sumbawa lebih baik dibanding dengan kualitas induk udang asal perairan Banyuwangi dan asal tambak diukur dari berat spermatopora, persentase hidup spermatoza tinggi, dan persentase abnormalitas spermatoza rendah yaitu $25,96 \%$.

\section{KESIMPULAN}

- Induk udang windu jantan asal perairan Sumbawa memberikan keragaan spermatozoa lebih baik bila dibandingkan dengan keragaan spermatozoa udang asal perairan Banyuwangi dan udang asal tambak

- Induk jantan udang windu dari perairan Sumbawa mempunyai bobot spermatopora sebesar $0,126 \mathrm{~g}$; jumlah spermatozoa sebesar $192.998 \times 10^{3} \mathrm{sel}$, persentase hidup spermatozoa sebesar $(79,80 \%)$, dan persentase abnormalitas spermatozoa sebesar $25,96 \%$.

\section{UCAPAN TERIMA KASIH}

Disampaikan terima kasih kepada A. Gufron Arif, Putu Suarjana, dan Usman teknisi litkayasa pada Balai Besar Riset Perikanan Budidaya Laut, Gondol, atas bantuannya selama pelaksanaan penelitian ini.

\section{DAFTAR PUSTAKA}

Alfaro, J. 1993. Reproductive quality evaluation of male Penaeus stylirostris from grow-out pond. Journal of The World Aquaculture Society, 24(1): 6-11.

Alfaro, J. and X. Lozano. 1993. Development and deterioration of spermatophores in pond-reared Penaeus vannamei. Journal of The World Aquaculture Society, 24(4): 522-529.

Anonymous. 2002. Do fish farms pollute the marine environment?. WWw aqua-media.org/home/FAO/ Answers/ans15en.asp (7 Maret 2002).

Brown, A. Jr., J.P. Mcvey, B.S. Middleditch, and A.L. Lawrence. 1979. Maturation of white shrimp (Penaeus setiferus) in captivity. Proceedings World Mariculture Society, 10: 435-444.

Gomes, L.A.O and J.H. Primavera. 1993. Reproductive quality of male Penaeus monodon. Aquaculture, 122: 157-164.

Heitzman, J.C., A. Diter, and Aquacop.1993. Spermatophore formation in the white shrimp, Penaeus vannamei Boone 1931: Dependence on the intermoult cycle. Aquaculture, 116: 91-98.

Leung-Trujillo, J.R. and A.L. Lawrence. 1985. The effect of eyestalk ablation on spermatophore and sperm quality in Penaeus vannamei. Journal of the World Mariculture Society, 16: 258-266. 
Leung-Trujillo, J.R. and A.L. Lawrence. 1987. Observation on the decline in sperm quality of Penaeus setiferus under laboratory. Aquaculture, 65: 363-370.

Lante, S. dan Haryanti. 1997. Pematangan gonad udang putih (Penaeus indicus) asal tambak dengan metode ablasi yang berbeda. J. Pen. Per. Indonesia, 3(3): 9-12.

Lante, S., Haryanti, dan S. Tsumura. 1997. Pengamatan spermatophora udang windu (Penaeus monodon Fab.) asal Tambak pada ukuran yang berbeda. Prosiding Simposium Perikanan Indonesia II, p. $231-233$.

Lante, S. 1998. Keragaan spermatofora udang windu (Penaeus monodon Fab.) asal lingkungaan tekstur dasar yang berbeda. Prosiding seminar Teknologi Perikanan Pantai, p. 104-107.

Lante, S. dan S. Tsumura. 2004. Produksi induk udang windu (Penaeus monodon Fab.) pada berbagai tipe dasar wadah budidaya dan pematangan gonadnya, $10 \mathrm{pp}$. (un publish).

Moria, S.B., Haryanti., I G.N. Permana, dan K. Sugama. 2002. Marka genetik untuk variabilitas pertumbuhan udang windu, Penaeus monodon dari sumber induk berbeda melalui analisis MT-DNA-RFLP. J. Pen. Per. Indonesia, 6(5): 1-9.

Motoh, H. 1981. Studies on the fisheries biology of the giant tiger prawn, Penaeus monodon, in the Philippines. Technical Paper No. 7. Aquaculture Department, Southeast Asian Fisheries Development Center, Tigbauan, lloilo, Philippines, 128 pp.
Nalbandov, A.V. 1990. Fisiologi Reproduksi pada Mamalia dan Unggas. Universitas Indonesia (UIPress), $378 \mathrm{pp}$.

Nurdjana, M.L. 1985. Pengaruh ablasi mata terhadap perkembangan telur dan embryo serta kualitas larva udang windu (Penaeus monodon Fab.). Disertasi. Universitas Gadjah Mada, Yogyakarta, $438 \mathrm{pp}$.

Pratoomchat, B.S., Piyatiratitivorakul, and P. Menasveta. 1993. Sperm quality of pond-reared and wild-caught Penaeus monodon in Thailand. Journal of the World Aquaculture Society, 24(4): $530-540$.

Ranoemihardjo, B.S., A. Kahar, and J.V. Lopez. 1980. Result of polyculture of milkfish and shrimp at the Karanganyar Provincial Demontration ponds. Bull. Brachishwater Aquaculture Vev. Cent., V(1\&2): 326334.

Subramoniam, T. 1990. Chemical composition of spermatophores in decapod crustaceans. Dalam. Crustacean Sexual Biology. Columbia Universitas Press, New York. p. 308-321

Tridjoko, K. Sugama, T. Sutarmat, dan S. Lante.1992 Survei pemanfaatan sumberdaya induk udang windu, Penaeus monodon, di perairan Nusa Tenggara. J. Pen. Budidaya Pantai, 8(3): 105-111.

Tridjoko, T. Sutarmat, T. Ruchimat, dan S. Lante. 1993. Pengaruh jenis pakan segar terhadap perkembangan gonad udang windu, Penaeus monodon. J. Pen. Budidaya Pantai, 9(2): 23-30. 
